\title{
La Ilustración Española y Americana (1869-1921). \\ Producto mercantil y cultural
}

\section{RESUMEN}

En este artículo se analizan las estrategias que Abelardo de Carlos y Almansa utilizó para colocar a La Ilustración Española y Americana en el mercado editorial mexicano. Destaca la competencia editorial que significó para ese editor la labor de los impresores franceses que distribuían con éxito El Correo de Ultramar. Muestra la trascendencia de las redes de periodistas, libreros, editores y escritores peninsulares residentes en México para promover el consumo, venta, circulación y distribución de la revista española, así como las relaciones entre miembros de la Real Academia Española, con sus pares de la Academia Mexicana, que alentaron tanto la lectura de esa publicación periódica como la colaboración de sus miembros.

Palabras clave: La Ilustración Española y Americana en México.

\section{ABSTRACT}

This article deals with analyzing the strategies that Abelardo Carlos y Almansa used to place La Ilustración Española y Americana in Mexico's publishing market. It stresses editorial competition meant for the publi-

1 Instituto de Investigaciones Bibliográficas, Universidad Nacional Autónoma de México, vieyra69@yahoo.com.mx. 
sher, the work of French printers who successfully distributed El Correo de Ultramar. It shows the importance of networks of peninsular journalists, booksellers, publishers and writers residents in Mexico, to promote consumption, sale, circulation and distribution of the Spanish magazine. As well as relations between members of the Real Academia Española, with their counterparts from the Mexican Academy, which encouraged both the periodic reading and the collaboration of its members.

Keywords: La Ilustración Española Americana in Mexico.

\section{INTRODUCCIÓN}

\section{L} cultura mexicana decimonónica. Los escritores y periodistas se inspiraban en ellas para elaborar sus propias producciones literarias, pero también había casos extremos en los que copiaban párrafos o artículos completos que reproducían sin permiso y los firmaban como autores originales. Esto motivó a los letrados españoles a solicitar la firma de convenios de propiedad literaria entre España y México, preocupación que estuvo latente a lo largo del siglo xIx y sobre la que se legisló hasta la siguiente centuria. ${ }^{2}$ Esas publicaciones también inspiraron al mercado editorial mexicano a imitar títulos, formatos, tamaños, número de páginas y folletines, entre otros aspectos materiales e intelectuales. Dichas revistas hacían posible que los mexicanos estuvieran actualizados en las vanguardias artísticas que tenían

2 Porfirio Díaz instruyó a José Algara, subsecretario de Relaciones Exteriores, a firmar un "Tratado entre los Estados Unidos Mexicanos y el Reino de España sobre propiedad literaria", el 19 de septiembre de 1903. http://cdigital.dgb.uanl.mx/ la/1080046961/1080046961_49.pdf [consultado 8 de diciembre 2016]. Más tarde, Alfonso Reyes y Fernando Espinosa de los Monteros signaron en Madrid, el 31 de marzo de 1924, un "Convenio entre los Estados Unidos Mexicanos y España, para garantizar y asegurar en ambos países la propiedad de las obras científicas, literarias y artísticas". Véanse también: Tratados sobre derecho de autor suscritos por México, México, Secretaría de Educación Pública/Instituto Nacional del Derecho de Autor, 2006, pp. 241-246, disponible en línea: http://www.indautor.gob.mx/documentos_publicaciones/4m.pdf [consultado 8 de diciembre 2016]. Sánchez García, Raquel, "La propiedad intelectual en la España contemporánea, 1847 1936", disponible en línea: http:// eprints.ucm.es/16991/1/PROPIEDA.pdf [consultado 8 de diciembre 2016]. 
lugar en Europa, ya que la prensa periódica española era a su vez un reflejo de la inglesa, francesa, alemana e italiana. Existen en México investigaciones que han señalado la importancia de la inmigración de escritores peninsulares que se sumaban al periodismo mexicano y contribuían como editores, redactores e impresores a introducir estilos literarios e innovaciones tecnológicas. ${ }^{3}$

Recientemente se han elaborado textos que se ocupan de estudios de caso sobre el impacto de las revistas españolas en la ciencia y las letras mexicanas. De este modo, puede citarse a Rodrigo Vega y Ortega, quien analizó la trascendencia de El Mundo Científico (1899-1911), revista catalana que

difundió en la República Mexicana los avances en la ciencia europea y mantuvo al lector mexicano actualizado en esfuerzos de la élite española por afianzar los lazos con Hispanoamérica, en especial los de tipo cultural para erigirse como la transmisora de la ciencia de vanguardia que se generaba en Europa en la lengua de la madre patria. ${ }^{4}$

En lo que toca a la literatura, Miguel Ángel Castro realizó un ejercicio comparativo sobre el sistema literario finisecular en México y España, a través de dos revistas mexicanas y dos españolas. ${ }^{5}$ Castro llega a la conclusión de que las revistas mexicanas El Mundo Ilustrado y el Cómico dejan ver similitudes con sus pares españolas Mundo cómico y La Ilustración Española y Americana. Particularmente enfatiza en la relación entre los directores de periódicas, tanto en México como en España, y el escritor asalariado, así como en la recepción de textos para un lector con poder adquisitivo, que aprecia una realidad social ajena a su estatus.

3 Mora, Pablo y Ángel Miquel (comp. y ed.), Españoles en el periodismo mexicano: siglos XIX y xx. México, Universidad Nacional Autónoma de México-Instituto de Investigaciones Bibliográficas, 2008.

4 Vega y Ortega, Rodrigo, "Microbios, fósiles y genes en una revista catalana en México. El Mundo Científico (1899-1911)", Adriana Pineda Soto y Fausta Gantús (coords.), Miradas y acercamientos a la prensa decimonónica, México, Universidad Michoacana de San Nicolás de Hidalgo/Red de Historiadores de la Prensa y el Periodismo en Iberoamérica, 2013, p. 369.

5 Castro, Miguel Ángel, "La elite se ilustra. Revistas literarias en España y México a fines del siglo XIX: el ejemplo de Clarín y Micrós", Elites en México y España. Estudios sobre política y cultura, México, Universidad Nacional Autónoma de México-Instituto de Investigaciones Históricas/Universidad de Cantabria, 2015, pp. 365-401. 
El artículo que aquí se presenta, abona en el estudio de las revistas españolas como modelos que los editores mexicanos reprodujeron porque consideraron que eran productos de calidad que merecían imitarse en México. Fundamentalmente, destacaré el caso de La Ilustración Española y Americana que el editor Abelardo de Carlos empleó para competir en el mercado editorial que los franceses monopolizaban en Hispanoamérica. Así, esta revista se enfrentó a El Correo de Ultramar como una oferta periodística producida en Europa para el consumo de Hispanoamérica. Centraré la atención en el análisis de las estrategias que su editor empleó para promover el consumo de esta revista. Así, demostraré la importancia que tuvieron los editores, libreros, periodistas y escritores peninsulares residentes en México, como parte de una red de publicidad que alentó la adquisición de esa periódica. Apuntaré las relaciones que los miembros de la Real Academia Española fomentaron con sus pares, asociados en la Academia Mexicana Correspondiente de aquélla. Referiré el caso de Victoriano Agüeros, quien tomó como modelo La Ilustración Española y Americana para elaborar la edición ilustrada de El Tiempo. Cabe advertir que, con el propósito de remarcar la larga vida de esta revista, el título de este artículo fija la temporalidad de 1869 a 1921 como los años en que apareció, pero aquí sólo abordaré, de manara panorámica, aspectos relevantes de su existencia, acaso en algunos momentos concentro la atención en la etapa que estuvo al frente de ella Abelardo de Carlos.

Como acabo de apuntar, en México esta revista ha merecido poca atención, por lo que es conveniente presentar una revisión sobre el momento de su fundación, sus años cruciales de desarrollo y la etapa de decadencia. En España, esa periódica ocupa un lugar muy importante en los catálogos de periódicos y periodistas, así como en las historias del periodismo y la literatura. ${ }^{6}$ En esas investigaciones se

6 La revisión historiográfica deja saber que desde 1894 a 2010, La Ilustración Española y Americana ha sido objeto de interés entre los historiadores de la prensa periódica y las letras peninsulares. De este modo, pueden citarse las siguientes obras: Eugenio Hartzenbusch, Apuntes para un catálogo de periódicos madrileños. Desde el año 1661 al 1870, publicada en 1894 en el establecimiento Tipográfico Sucesores de Rivadeneyra, Imprenta de la Real Casa, Edición facsimilar, España, Biblioteca Nacional/Ministerio de Cultura/Ollero y Ramos Editores, 1993. Manuel Ossorio y Bernard, Ensayo de un catálogo de periodistas españoles del siglo XIX, España, Imprenta y Litografía de J. Palacios, 1903. Pedro Gómez Aparicio, Historia del periodismo español. Desde la Gaceta de Madrid (1661) hasta el destronamiento de Isabel II, España, Editora Nacional, 1967. María Cruz 
ha evaluado la calidad de sus artículos, redactados por los escritores peninsulares de mayor renombre, la aplicación de avances tecnológicos, la excelente factura de sus grabados y fotografías que competían con los de otras revistas europeas, la trascendencia de los géneros literarios como la crónica, el ensayo y el reportaje gráfico. Así como el impacto de su recepción entre lectores con una posición económica elitista y su valor histórico para documentar la vida cotidiana de España durante la etapa de la Restauración al reinado de Alfonso XII. A continuación, destacaré los momentos más importantes desde su fundación, apogeo y declive.

\section{EL ORIGEN DE LA ILUSTRACIÓN ESPAÑOLA Y AMERICANA}

Los antecedentes de La Ilustración Española y Americana se remontan al 15 de enero de 1857, cuando José Gaspar Maristany y José Roig Oliveras establecieron El Museo Universal, al que apellidaron Periódico

Seoane, Oratoria y periodismo en la España del siglo XIX, España, Fundación Juan March/ Editorial Castalia, 1977. Giséle Cazottes, La presse periodique madrilene entre 1871 et 1885, Francia, Centre de Recherche sur les Litteratures Ibériques et Ibéroamericaines Modernes, Universite Paul Valerie, Montpellier, 1982. Felipe B. Pedraza Jiménez y Milagros Rodríguez Cáceres, Manual de literatura española. VII. Época del realismo, España, Cénlit Ediciones, 1982. María Cruz Seoane, Historia del periodismo en España, II. El siglo XIX, España, Alianza Editorial, 1983. Marta Palenque, Gusto poético y difusión literaria en el realismo español. La Ilustración Española y Americana (1869-1905), Sevilla, Ediciones Alfar, 1990. María Pilar Celma Valero, Literatura y periodismo en las revistas del fin de siglo. Estudio e indices (1888-1907), España, Ediciones Jucar, 1991. José Javier Sánchez Aranda y Carlos Barrera, Historia del periodismo español. Desde sus orígenes hasta 1975, España, Ediciones de la Universidad de Navarra, 1992. Guillermo Carnero Historia de la literatura española. Siglo XIX (I), España, Espasa-Calpe, 1997. Vivian Jara, "Imagen de América Latina en La Ilustración Española y Americana, en el siglo XIX", Latina. Revista de Comunicación Social (12 diciembre 1998), disponible en línea: www.ull.es/publicaciones/latina/a//02hvivian. htm [Consultado el 15 de diciembre de 2015]. Leonardo Romero Tobar, Historia de la literatura española. Siglo XIX (II). España, Espasa Calpe, 1998. Miguel B. Márquez, "D. Abelardo de Carlos y La Ilustración Española y Americana", Ámbitos, España, n. 13-14 (2005). María Cruz Seoane, María Dolores Saiz, Cuatro siglos de periodismo en España. De los avisos a los periódicos digitales, España, Alianza Editorial, 2007. Juan Miguel Sánchez Vigil Revistas ilustradas en España del romanticismo a la guerra civil, España, Ediciones Trea, 2008. Ma. del Pilar Palomo, Movimientos literarios y periodismo en España, España, Editorial Síntesis, 2010. 
de ciencias, literatura, artes, industria y conocimientos útiles. Luego de doce años de sostenerlo lo dieron en adopción, a cambio de cierta suma monetaria, al editor gaditano Abelardo de Carlos y Almansa (18221884), quien lo adquirió en noviembre de 1869 y al siguiente mes, el 25 de diciembre, le quitó el nombre que le habían dado sus primeros progenitores y lo bautizó con el de La Ilustración Española y Americana, denominación a la que agregó, a manera de subtítulo, Museo Universal de ciencias, artes, literatura, industria y conocimientos útiles. Este apellido era una forma de sostener su antigua identidad mientras adquiría fama con su nuevo nombre.

Vale la pena mencionar que los fundadores de El Museo Universal, luego llamado La Ilustración Española y Americana, fueron dos importantes editores, impresores y libreros catalanes que fundaron la compañía Gaspar y Roig en 1845, la cual estableció diversos proyectos editoriales como la Biblioteca Ilustrada de Gaspar y Roig, que se vendió en la República Mexicana. Por lo que respecta al padre adoptivo de esta publicación, Abelardo de Carlos y Almansa tenía su residencia en Cádiz, donde elaboró con éxito La Revista Médica y La Moda Elegante, esta última la compró a Francisco Flores Arenas, quien la sostuvo desde 1842 con el nombre de La Moda.De Carlos tuvo gran interés en adquirir El Museo Universal que, luego de editarlo por doce años, Gaspar y Roig decidieron vender. A finales de 1869, Abelardo abandonó Cádiz y fijó su residencia en Madrid, en donde creó una gran empresa basada en la edición de La Ilustración Española y Americana y La Moda Elegante, publicaciones que facturó con gran esmero y en las que tuvo la misión de sostener a la vanguardia de la tecnología europea. De esta manera, De Carlos construyó una imprenta dedicada exclusivamente a sus publicaciones y buscó que el papel en que se imprimían fuera el de la mejor calidad. Tanto Gaspar y Roig como De Carlos tenían el objetivo de establecer en España una revista que siguiera el modelo de otras publicaciones europeas ilustradas como Illustrated London News, L'Illustration, Le Monde Illustré, Illustrite Zeitung y La Illustrazione Italiana. De Carlos estaba seguro que su empresa editorial constituía un acto a favor de engrandecer el nombre de su patria, tenía "la perspectiva de cumplir un deber, demostrando que España, a pesar de las desgracias que la abruman, cuenta con un periódico que, como La Ilustración Española y Americana, en nada desmerece de los mejores que en el 
extranjero se publican". ${ }^{7}$ Por otra parte, De Carlos tenía la intención de fijar una publicación que compitiera con El Correo de Ultramar, que elaboraban editores franceses y distribuían en Hispanoamérica.

Además de conservar el subtítulo de la revista que adquirió, De Carlos también respetó y consideró sus años de vida, ya que en la organización de los primeros números de La Ilustración Española y Americana se fijó que se trataba del año catorce. Cabe anotar que De Carlos aprovechó la fecha del 25 de diciembre, en que la Iglesia católica celebra el nacimiento de Cristo, para establecer una nueva etapa de la publicación, lo cual habla de sus creencias religiosas y del respeto a los valores establecidos por la nobleza española a la cual respaldó en ésta y otras publicaciones.

Los primeros dos años de La Ilustración Española y Americana fueron difíciles porque compitió con La Ilustración de Madrid, que dirigía Gustavo Adolfo Bécquer bajo la égida artística de Bernardo Rico y con la dirección financiera de Eduardo Gasset. Esta revista gozó de la colaboración de destacadas plumas como las de Antonio Cánovas del Castillo, Eusebio Blasco y María del Pilar Sinués de Marco. El investigador español Pedro Gómez Aparicio, considera que los dibujos realizados por Valeriano Bécquer constituyeron un gran atractivo para los suscriptores de la revista. ${ }^{8}$ La publicación paralela de ambas periódicas ilustradas representó para De Carlos un gran reto del que salió triunfante en 1871, año en el que Gasset evaluó que su revista se hallaba en decadencia y decidió vendérsela a De Carlos. Así, el editor gaditano fusionó La Ilustración de Madrid con La Ilustración Española y Americana, a la que convirtió en una publicación de calidad, equiparable a las mejores de su tipo en Europa. Hay que enfatizar en que la aceptación de sus lectores hizo posible que su frecuencia cambiara; originalmente se había publicado cada quince días, pero a partir del 5 de agosto de 1870 se distribuyó tres veces al mes y posteriormente fue semanal.

La Ilustración Española y Americana fue una empresa familiar que Abelardo de Carlos administró hasta 1881, tres años antes de su muerte, cuando la dejó en manos de su hijo Abelardo José de Carlos y Hierro (1848-1910), quien estuvo al frente de su edición convirtiéndola

7 "A los señores suscritores a La Ilustración Española y Americana", La Ilustración Española y Americana, a. 17, n. 19 (16 mayo 1873), p. 298.

8 Historia del periodismo español. De la revolución de septiembre al desastre colonial, España, Editorial Nacional, 1971, pp. 608-609. 
en una revista a la vanguardia tecnológica. ${ }^{9}$ Contrario al interés empresarial de su padre, José de Carlos dejó de ocuparse del crecimiento y trascendencia de la revista, por lo que empezó a decaer. Marta Palenque apunta que poco a poco, La Ilustración Española y Americana quedó a un lado frente a revistas de reciente creación, como Blanco y Negro, que se convirtió en una de sus principales competidoras.

Posteriormente, La Ilustración Española y Americana quedó en manos de Alejandro Moreno y Gil de Borja, esposo de una de las hijas de Abelardo de Carlos, que la dirigió hasta 1914, cuando la vendió a Ricardo Picovea, el cual descuidó su elaboración, lo que generó su ruina y desaparición el 30 de diciembre de 1921. Quizá entre las causas de su declive, además del desinterés del hijo de Abelardo de Carlos y la competencia que anota Marta Palenque, habrá que considerar que entre 1914 y 1920, Europa atravesaba por una etapa de crisis económica provocada por los estragos de la Primera Guerra Mundial, que afectó la producción de este tipo de revistas artísticas. La trascendencia histórica, literaria y cultural de La Ilustración Española y Americana en España es tal, que se le considera como la revista que marcó la transición del grabado a la fotografía. Cabe destacar, además, que sus números sueltos y volúmenes se cotizan en el mercado del libro antiguo español. Pasemos ahora a conocer las características físicas de esta publicación.

\section{LA MATERIALIDAD DE LA REVISTA}

La Ilustración Española y Americana es una revista ilustrada cuyo cuerpo lo constituyen 16 páginas de 37 x 28 centímetros que crecieron al paso de los años, debido al éxito editorial y a la implementación de novedades tecnológicas introducidas por De Carlos. El cabezal fue elaborado por el grabador Bernardo Rico y representaba las joyas arquitectónicas de España: la Alhambra de Granada, la Giralda de Sevilla, la Plaza Mayor de Madrid, entre otras, enmarcadas por algún paisaje exuberante de América, un globo terráqueo y otros instrumentos que simbolizan las

9 Márquez, Miguel B. menciona que en 1881 la empresa de De Carlos tenía un capital de 800,000 pesetas y que al siguiente año la cantidad se incrementó y entró a formar parte del negocio Isidoro de Carlos Hierro, así como los esposos de sus hijas, Trinidad y Milagros, Alejandro y Manuel Moreno Gil de Borja. 
ciencias y las artes. Este grabado también cambió con el tiempo. Sus páginas fueron ilustradas por Eduardo Rosales y otros dibujantes. Cabe citar el caso del pintor Ramón Padró (1848-1915), quien estuvo en la inauguración del Canal del Suez, en noviembre de 1869, y realizó croquis y fotografías "tomados de ex profeso" para que De Carlos los incluyera en La Ilustración Española y Americana. ${ }^{10}$ Se dice también que sus ilustradores captaron la guerra franco-prusiana (1870-1871) y el conflicto carlista de 1872 a 1876 . Los suscriptores pudieron apreciar las batallas, las ciudades, los campamentos y los retratos de los protagonistas de esos hechos históricos, complementados con excelentes crónicas de los acontecimientos. De Carlos promovió la venta de suscripciones temporales a la revista, sólo por la etapa en que se ocupó de acontecimientos relevantes como la Exposición Universal de Viena (1873).

Anualmente, De Carlos ofrecía a sus suscriptores encuadernar, a bajo costo, los ejemplares en dos volúmenes, que llevaban un grabado en la página de guarda, con lujosas tapas de color rojo, estampadas en negro y oro, correspondientes al primer y segundo semestres del año. Además, La Ilustración Española y Americana iba acompañada de un Almanaque. Este proyecto editorial de Abelardo de Carlos, dedicado a las élites españolas, fue cobijado con el apoyo de la monarquía. Cabe anotar que las publicaciones de De Carlos salieron de la Imprenta Estereotipia y Galvanoplástica de Aribau y Ca. (Sucesores de Rivadeneyra), que eran los impresores del rey de España.

\section{LA DISTRIBUCIÓN DE LA ILUSTRACIÓN ESPAÑOLA Y AMERICANA}

Esta revista se distribuyó en España y otros países de Europa, aunque también tenía como objetivo primordial llegar a Hispanoamérica para incidir tanto en el intercambio mercantil como cultural entre su patria y las antiguas colonias. De Carlos trataba de captar el mercado hispanoamericano que los editores franceses monopolizaban con el reparto fraudulento de obras literarias de autores peninsulares que distribuían sin pagar derechos de autor. Además, el editor estaba se-

10 "Advertencias", La Ilustración Española y Americana, a. 14, n. 1, (25 dic. 1869), p. 16. "Ramón Padró y Pedret", Wikipedia. La Enciclopedia Libre, disponible en línea: [Consultado 5 de diciembre de 2016] https://es.wikipedia.org/wiki/Ramon_Padro_y_Pedret. 
guro de que era importante establecer lazos que unieran la lengua y literatura españolas con las antiguas colonias. En su cabezal, La Ilustración Española y Americana establecía que se vendía en Argentina, Cuba, Filipinas y Puerto Rico, puntos de comercio importantes para la época. A este respecto, José Fernández Bremón apuntó:

Cuando D. Abelardo de Carlos empezó a entablar sus relaciones editoriales con América, apenas existían comunicaciones con la mayor parte de aquellos estados, ni era posible hallar corresponsales, ni había protección, ni tratados, ni medios de constituir ninguna empresa formal y duradera. Las dificultades vencidas hasta llegar a conseguir una organización sólida y regular, tan sencilla como la que actualmente funciona, forman una oscura pero verdadera epopeya mercantil, de que solo quedan rastros en los archivos del periódico. ${ }^{11}$

Ante el difícil panorama comercial que describe Fernández Bremón, ¿qué mecanismos empleó De Carlos para posicionar su producto entre el consumidor mexicano? Cabe aventurar que las estrategias comerciales del editor gaditano se enfocaron en emplear sus relaciones con sus paisanos residentes en México, que se movían en el ambiente editorial y librero. Desde luego, carezco de cartas u otros documentos que den fe de esos afanes, aventuro esta hipótesis en el hecho de que los peninsulares residentes en la República Mexicana, promocionaron esa revista. De este modo, Anselmo de la Portilla, Adolfo Llanos y Telésforo García se encargaron de publicitarla en sus periódicos, La Iberia, La Colonia Española y La Libertad. Así como destacar la trascendencia literaria de su contenido y la calidad de sus ilustraciones. Por otra parte, el librero peninsular Juan Buxó la distribuía en la Librería Madrileña.

El viaje que La Ilustración Española y Americana hacía de Madrid a la capital de la República Mexicana duraba aproximadamente dos meses. En el trayecto, la revista sufría las condiciones de un traslado inadecuado para la fragilidad y delicadeza de su cuerpo. Además, el correo mexicano manejaba sin cuidado los paquetes de periódicos, tanto nacionales como extranjeros, problema que aquejó su distribución a lo largo del siglo XIx. No obstante, algunos editores trataban de ofrecer un mejor servicio para ganar clientes. Así, la compañía del librero Juan

11 Fernández Bremon, José, "Crónica", en La Ilustración Española y Americana, año 28, no. 13 (8 abr. 1884), pp. 211, 214. 
de la Fuente Parres se comprometía a entregarla puntualmente y en buenas condiciones tanto a los suscriptores residentes en la capital de la República Mexicana como a los del interior del país. Parres apuntó:

Hay muchos suscriptores de fuera de la capital, a quienes se les sirve una suscripción directamente, y como muchas veces llega un solo número, este se estropea en la valija y llega a poder del suscriptor inservible; y para evitar esto tenemos en los Estados y distritos, nuestros agentes que se ocupan en servir las suscripciones, y estos las cobran como mejor convenga al señor suscriptor, adelantado o por números. ${ }^{12}$

La Ilustración Española y Americana también circuló en la provincia mexicana; en Zacatecas podía adquirirse en la Librería Universal y en Yucatán en la Librería Meridiana de Cantón. La publicidad y venta de La Ilustración Española y Americana incluyó a los españoles residentes en México, pero también la anunciaban y recomendaban periódicos mexicanos, tanto de carácter liberal como conservador. Entre ellos hay que citar a El Siglo Diez y Nueve y La Voz de México, respectivamente. En Mérida, La Razón del Pueblo, Periódico Oficial del Estado Libre y Soberano de Yucatán, comentó los artículos que la revista española publicó referentes a nuestro país, entre ellos la biografía de Benito Juárez. En este sentido, valga decir que cada periódico mexicano hacía la lectura de La Ilustración Española y Americana de acuerdo a sus intereses. Así, por ejemplo, La Voz de México, periódico redactado por conservadores, el 3 de abril de 1872 destacó que la revista peninsular había entregado a sus lectores el retrato de Carlos Marx, jefe de la Internacional y amenaza de la sociedad. Los redactores de La Voz de México decían que causaba "horror esta fisonomía, y sin leer el nombre se adivina que pertenece a uno de esos genios siniestros del mal". ${ }^{13}$

Por su parte, los redactores de La Democracia, periódico liberal, señalaron que La Ilustración Española y Americana difundía en España una buena imagen de Sebastián Lerdo de Tejada y lo colocaba como favorito para triunfar en las elecciones para presidente de la República. Al mismo tiempo, los redactores de este diario mexicano destacaron el interés de la revista española por lograr que en México reinara la paz.

12 Parres y Ca, J. F. "La Moda Elegante y La Ilustración Española y Americana". En La Libertad, a. 2, n. 44 (22 feb. 1879), p. 3

13 "La Ilustración Española y Americana". En La Voz de México, t. 3, no. 78 (3 abr. 1872), p. 3. 
Como mencioné antes, De Carlos tenía un gran ánimo empresarial y la intención de establecer productos competitivos con el mercado editorial de habla hispana en América, que controlaba Francia. Cuando compró El Museo Universal en 1869, que atrás referí, cambió el nombre por el de La Ilustración Española y Americana, ya existía El Correo de Ultramar, revista ilustrada que circulaba desde 1842 en París y se distribuía en los países hispanoamericanos. Probablemente, en México empezó a recibirse en el año de 1843, ya que a partir de marzo de ese año El Siglo Diez y Nueve tradujo notas de esa revista francesa. ${ }^{14}$

Su editor Xavier de Lasalle se inspiró en la revista británica The Illustrated London News, fundada en Inglaterra ese mismo año. Al respecto, Lasalle señaló:

No pretendemos atribuirnos la idea fundamental de esta nueva y brillante forma de la prensa periódica, idea perteneciente a la Inglaterra y que sucesivamente con extraordinaria aceptación han imitado cuasi todas las naciones continentales de Europa. Con este tino exquisito y sensatez proverbial que le caracteriza, comprendió el pueblo inglés la importancia de semejante empresa; así obtuvo el más prodigioso resultado; numerosas pruebas de simpatía y reiteradas ofertas pecuniarias fueron prodigadas a sus directores, y pocos meses después de su aparición, la Ilustración Inglesa, tirada a más de cien mil ejemplares, leída en alta voz en las reuniones de familia, saboreada aun más que el té humeante por las jóvenes inglesas incesantemente hojeada por los niños y personas entusiastas, o ricamente encuadernada en la Biblioteca del literato, era proclamada por uno de los más eminentes publicistas de la Gran Bretaña, una de las más filantrópicas y civilizadoras del siglo. ${ }^{15}$

Puede apreciarse, pues, que Lasalle imitó la labor de los editores ingleses de producir una revista ilustrada, pero también se mostró interesado en que tuviera valor literario y que cubriera el mercado hispanoamericano al que los editores londinenses se habían acercado tiempo atrás. Lasalle contrató a los mejores escritores españoles

14 El Fondo Reservado de la Hemeroteca Nacional de México conserva un suplemento de El Correo de Ultramar, correspondiente al año de 1844, así como ejemplares que van de 1853 a 1884 .

15 Lasalle y Mélan, X|avier] de, "A nuestros lectores", El Correo de Ultramar, a. 12, n. 1, (1853), pp. 1-2. 
que colaboraron en la redacción de El Correo de Ultramar. Aunque, como apunta Catherine Sablonniere, en sus primeros años la revista fue escrita por los franceses Granier de Cassagnac y Rosemond de Beauvallon a partir de 1851 el cuerpo de redactores se conformó con importantes literatos españoles como Eugenio Ochoa, Juan Eugenio Hartzenbusch, Manuel Cañete, Mariano Urrabieta, Emilio Castelar, Manuel Fernández y González, Manuel Ossorio y Bernard, Eduardo y Eusebio Asquerino. ${ }^{16}$ Cabe enfatizar que la mayor parte de ellos formaban parte de la Real Academia Española y tenían experiencia en la redacción de periódicas literarias. Por otra parte, Sablonniere apunta que El Correo de Ultramar representó un puente cultural entre Francia, España e Hispanoamérica y se dirigió particularmente a las élites cultas de los países de habla hispana. Veamos ahora de qué manera De Carlos contrató algunos productores de aquella revista francesa.

\section{LA REVISTA Y LOS MIEMBROS DE LA REAL ACADEMIA ESPAÑOLA}

De Carlos sabía el lugar que tenían los escritores españoles como autores y traductores de libros editados en Francia, que inundaban el "mercado floreciente de Hispanoamérica", por ello cuando salió de Cádiz y se estableció en Madrid empezó a relacionarse con esos hombres de letras, gran parte de los cuales integraban la Real Academia Española. Pura Fernández, estudiosa del comercio del libro en Francia, España e Hispanoamérica, ha señalado los afanes de los editores peninsulares por participar en la distribución de obras en el mercado hispanoparlante. ${ }^{17}$ La autora también nos hace saber que ya desde 1856 Abelardo de Carlos se ocupaba de introducir libros franceses en España cuyo destino era su distribución en Centro y Sudamérica. ${ }^{18}$ De esta manera, podemos apreciar que la experiencia de De Carlos en las operaciones editoriales a nivel internacional guió la expansión de La

16 Sablonniere, Catherine, "El Correo de Ultramar (1842-1886) y la ciencia: entre labor educativa y propaganda política", disponible en línea: [Consultado 2 de enero de 2014] http://historiadoresdelaprensa.com.mx.

17 Fernández, Pura. "El monopolio del mercado internacional de impresos en castellano en el siglo XIX. Francia, España y 'la ruta' de Hispanoamérica". En Bulletin Hispanique, t. 100, n. 1, (1998), pp. 165-190.

18 Fernández, Pura. "El monopolio...", p. 176.

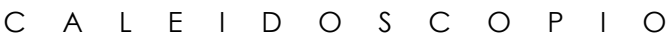


Ilustración Española y Americana como un producto tanto para el mercado español como hispanoamericano.

Así pues, conocedor de la producción de los escritores españoles que colaboraban con editores franceses para cubrir las necesidades del lector hispanoamericano, De Carlos se interesó en contratarlos para que dieran renombre a La Ilustración Española y Americana, y que ésta se convirtiera en la competencia que implicaba la estabilidad de El Correo de Ultramar entre los consumidores hispanoamericanos de revistas. ${ }^{19}$ Sobre este aspecto, Pura Fernández señala que:

Hartzenbusch, Bretón de los Herreros, García Gutiérrez, Martínez de la Rosa, J. N. Gallegos, Zorrilla, pero sobre todo Larra y Espronceda -convertidos estos últimos en oráculos por su producción literaria y su pensamiento liberal-, difundieron su magisterio en Hispanoamérica, fundamentalmente a través de ediciones impresas en Francia y multiplicadas, con posteridad, en los países receptores. ${ }^{20}$

Fernández también cita las palabras de Juan Valera, quien abogaba por publicar libros castellanos para América con el propósito de lograr el esplendor y difusión de la literatura española, lo cual "anularía y sepultaría para siempre en el olvido las malas y groseras ediciones que salen de las prensas de París, atestadas de feísimas e intolerables erratas e hijas de un sórdido anhelo de lucro". ${ }^{21}$

19 La lista de suscriptores de El Correo de Ultramar deja ver que se recibía en diversos puntos de Hispanoamérica. En México, durante el año de 1853, podía adquirirse con Boix, Besserer y Compañía. La ilustración que adorna el cabezal de los ejemplares correspondientes a 1864 muestra su intención de cubrir a los lectores y clientes de España e Hispanoamérica; se muestran dos planos divididos, por lo que podríamos señalar como el océano Atlántico que puede unirse con un barco, cuya colocación en medio del Atlántico resulta un puente entre América y Europa. Aparecen también en el lado izquierdo paisajes, monumentos arquitectónicos y una pareja de hombre y mujer que pueden identificarse como propios de algún país de habla hispana, del otro lado hay los mismos elementos, pero que definen que se trata de un paisaje europeo, la vestimenta de la pareja bien podría identificarse como la de una mujer y un varón españoles.

20 Fernández, Pura, "En torno a la edición fraudulenta de impresos españoles en Francia: La Convención Literaria Hispano-Francesa (1853)", Estudios de literatura española de los siglos XIX y XX. Homenaje a Juan Díez Taboada, España, Consejo Superior de Investigaciones Científicas, 1998, p. 204.

21 Palabras de Juan Valera citadas en Pura Fernández. "En torno a la edición fraudulenta de impresos españoles...", p. 208. Cabe mencionar que en México, Arnulfo Uriel 
Así pues, De Carlos hizo frente a sus rivales a través de alianzas con los escritores miembros de la Real Academia Española, que tenían la experiencia de redactar textos que se consumían con éxito por los lectores de El Correo de Ultramar. El editor gaditano hizo pagos atractivos a los académicos, de esa manera, en las páginas de La Ilustración Española y Americana podía leerse a José Zorrilla, Ramón de Campoamor, Juan Valera, Leopoldo Alas Clarín, José de Castro y Serrano, Manuel Cañete, Gustavo Adolfo Bécquer, Antonio Arnao, Manuel del Palacio y Ramón Mesonero Romanos, entre otros. Poco a poco, La Ilustración Española y Americana alcanzó un gran prestigio y se colocó como competidora de El Correo de Ultramar.En lo que respecta al mercado mexicano, De Carlos alentó a los miembros de la Real Academia Española a fortalecer los lazos de unidad a través del idioma y las letras castellanas con los escritores que conformaron la Academia Mexicana Correspondiente de la Española. La relación entre académicos españoles y escritores mexicanos que se afanaron por establecer la Academia Mexicana puede marcarse en 1865, cuando la Real Academia Española decidió establecer academias correspondientes en Hispanoamérica. ${ }^{22}$

Además, De Carlos empleó su relación con empresarios peninsulares avecindados en México, quienes también estaban ligados al medio intelectual de nuestro país, para promover el consumo de La Ilustración Española y Americana. De este modo, vale citar las líneas del periódico La Libertad, redactado por periodistas mexicanos y con el respaldo económico del empresario santanderino Telésforo García, que refieren tanto la importancia de la revista en el marcado editorial europeo como la difusión que daba en España a los escritores mexicanos, primordialmente a los que formaban parte de la Academia Mexicana Correspondiente de la Española.

de Santiago se ha ocupado de evaluar el lugar de la edición y distribución de libros franceses en la República Mexicana durante el siglo XIX, como una forma de ubicar la historia internacional del libro. Véanse sus artículos "Editar en Francia, siglo XIX. La 'librería española' para América", Anuario de Investigación 2005. Universidad Autónoma Metropolitana, (2006), pp. 682-698, y "Las Ciencias Sociales en América Latina: Siglo XIX: Ediciones como primeras fuentes". Argumentos. Estudios críticos de la sociedad, (enero-abril 2013), pp. 13-35.

22 Vieyra Sánchez, Lilia, "La Real Academia Española y la Academia Mexicana Correspondiente de la Española. Dos instituciones elitistas, 1865-1875", Elites en México y España. Estudios sobre política y cultura, México, Universidad Nacional Autónoma de México-Instituto de Investigaciones Históricas Universidad de Cantabria, 2015, p. 298. 
La Ilustración Española y Americana, uno de los periódicos más importantes en su clase que ven la luz pública en Europa, viene publicando hace tiempo las biografías de nuestros literatos más distinguidos y consagrándoles una preferencia que nunca podremos agradecer bastante. En el número correspondiente al 30 de julio último ha dado a luz un suplemento donde encontramos la del ilustrísimo señor obispo de Tamaulipas, que reproducimos hoy, y la de Don José María Roa Bárcena que reproduciremos mañana. Ya se han publicado otras de escritores no menos prominentes, y se nos dice que están para publicarse algunas más que puedan dar idea en el extranjero de nuestra generación literaria. ${ }^{23}$

Por otra parte, De Carlos desarrolló un concepto editorial que contemplaba la elaboración de publicaciones para cubrir el mercado de suscriptores del sexo femenino al que le ofreció las revistas La Moda Elegante (1842-1927) y El Bazar (1874-1875). ${ }^{24}$ En la capital de la República Mexicana, La Moda Elegante circuló entre las damas mexicanas que, al igual que las españolas, adquirían esta revista por los patrones de ropa femenina e infantil, modelos de bordado, recetas de cocina, reglas de etiqueta, modas, partituras musicales y novelas, entre otras. Pasemos a referir la colocación de esa revista en el gusto del consumidor mexicano.

\section{LA ILUSTRACIÓN ESPAÑOLA Y AMERICANA, LAZO DE UNIÓN ENTRE ACADÉMICOS DE MÉXICO Y ESPAÑA}

Como mencioné antes, esta revista madrileña permite documentar los afanes de un grupo de escritores peninsulares, miembros de la Real Academia Española, por estrechar lazos de fraternidad entre España e Hispanoamérica, a través de las letras castellanas. Atrás apunté que los

23 "Honor a nuestro país", La Libertad, México, a. 2, n. 210 (9 de septiembre de 1879), p. 3.

24 El Fondo Reservado de la Hemeroteca Nacional de México cuenta con La Moda Elegante correspondiente a 1875, 1876, 1884, 1900, 1907, 1908 y 1913. La prensa periódica mexicana registra que La Moda Elegante se distribuía en la República Mexicana desde 1865. En 1871 podía adquirirse en la Ciudad de México en la Librería de Rosa y Bouret, establecimiento que expendía libros franceses, españoles y otros importados de Europa, lo que deja ver que pese a todos sus esfuerzos, los productos periodísticos de De Carlos seguían comercializándose por franceses. 
académicos peninsulares tenían el interés de evitar el monopolio de las editoriales francesas sobre la distribución ilegal de libros escritos o traducidos por españoles. Además, estos académicos se propusieron fijar la hegemonía de la cultura española en lo que fueron sus antiguas colonias. En España, la participación de escritores mexicanos en La Ilustración Española y Americana ha sido documentada por la investigadora Ma. Isabel Hernández Prieto, quien clasificó sus nombres, número de colaboraciones y títulos de sus artículos durante el periodo de 1871 a $1896 .{ }^{25}$

Cabe destacar entre ellos a Alejandro Arango y Escandón (18211883), Joaquín García Icazbalceta (1825-1894), ${ }^{26}$ Ignacio Montes de Oca y Obregón (1840-1921), José María Roa Bárcena (1827-1908), José Sebastián Segura (1822-1889), Victoriano Agüeros (1854-1911), José Peón y Contreras (1843-1907) y Vicente Riva Palacio (1832-1896), los cuales tenían la particularidad de que formaban parte de la Academia Mexicana Correspondiente de la Española. Cabe advertir sobre las diferencias generacionales de estos miembros, así como el hecho de que la mayoría tenía relación con las ideas conservadoras, excepto Riva Palacio, quien durante toda su vida simpatizó con el liberalismo. A través de La Ilustración Española y Americana, los escritores mexicanos difundieron sus producciones, pero también se ocuparon del movimiento cultural que tenía lugar en la República Mexicana. En este sentido, puede mencionarse el artículo de Agüeros, quien redactó la biografía de Ignacio Cumplido, renombrado editor e impresor mexicano de periódicos, revistas y libros. Por otra parte, la revista peninsular incluyó las producciones de los escritores mexicanos y ocasionalmente sus retratos, tanto para cumplir con los fines gráficos de la publicación como para que se les conociera físicamente en el Viejo Continente y en los países de Hispanoamérica. Los miembros de la Real Academia Española promovieron la unidad cultural con los mexicanos a través de las letras. Hacer posible estos afanes requería que se conocieran, que se comunicaran sus objetivos y que juntos lucharan por cristalizarlos. Aunque los separaba la distancia geográfica, este impedimento

25 En Anales de literatura hispanoamericana, Madrid, España, n. 24 (1995), pp. 205-223.

26 El primer artículo que se publicó de este autor en La Ilustración Española y Americana corresponde al del 5 de diciembre de 1871, cuatro años antes de la fundación de la Academia Mexicana, probablemente su inclusión se debió a la amistad de don Joaquín con académicos y libreros españoles. 
fue salvado a través de la comunicación epistolar que sostuvieron y que generó una importante amistad que contribuyó a estrechar lazos literarios entre ambos países. A este respecto, hay que citar las obras de Pablo Mora, Ricardo Pérez Montfort y Emma Rivas Mata, quienes se han ocupado de la correspondencia que medió entre aquellos. ${ }^{27}$

De este modo, pueden mencionarse las cartas que acercaron a Marcelino Menéndez y Pelayo con la obra de García Icazbalceta, Roa Bárcena, Riva Palacio, Rafael Ángel de la Peña y Francisco Sosa. Además, esta cercanía influyó para que los escritores mexicanos sugirieran y previnieran los nombres de sus compatriotas que podían ser considerados como miembros de la Academia Mexicana Correspondiente de la Española. Emma Rivas Mata documenta que García Icazbalceta le solicitó a Manuel Tamayo y Baus, quien fungía dentro del cuerpo directivo de la Real Academia Española, que aconsejara a los académicos peninsulares que tuvieran cuidado en los nombramientos de los mexicanos para evitar que las diferencias ideológicas y políticas influyeran en la disolución de la Academia. ${ }^{28}$ Pérez Montfort dice que cuando falleció Manuel Payno, miembro de la Academia, Riva Palacio sugirió a Menéndez y Pelayo que su lugar fuera ocupado por Juan A.

27 Mora, Pablo estudia la presencia de Casimiro del Collado y Anselmo de la Portilla en las letras mexicanas. "Españoles en México en el siglo XIX: historiografía, crítica y periodismo literario", Ángel Miquel, Jesús Nieto Sotelo y Tomás Pérez Vejo (comps.) Imágenes cruzadas. México y España, siglos XIX y XX. México, Universidad Autónoma del Estado de Morelos, 2005, pp. 163-197. Por su parte, Ricardo Pérez Montfort documenta la correspondencia que Marcelino Menéndez y Pelayo sostuvo con académicos mexicanos, como García Icazbalceta, Roa Bárcena, Riva Palacio, Rafael Ángel de la Peña y Francisco Sosa, durante los últimos veinte años del siglo XIX. "La intelectualidad conservadora mexicana y Marcelino Menéndez y Pelayo. Impresiones de una relación a finales del siglo XIX y principios del XX". En Aurora Cano Andaluz, Manuel Suárez Cortina y Evelia Trejo (eds.), Cultura liberal, México y España. 1860-1930. España: PUbliCan Ediciones de la Universidad de Cantabria/Universidad Nacional Autónoma de México-Instituto de Investigaciones Bibliográficas, 2010, pp. 277-295. Emma Rivas Mata. "Corresponsales hispanos del bibliógrafo mexicano Joaquín García Icazbalceta". En Agustín Sánchez Andrés y Juan Carlos Pereira Castañares (coords.), España y México. Doscientos años de relaciones, 1810-2010. México: Universidad Michoacana de San Nicolás de Hidalgo-Instituto de Investigaciones Históricas/Comisión para el Bicentenario de la Independencia y el Centenario de la Revolución/Comisión Española de Historia de las Relaciones Internacionales, 2010, pp. 99-123.

28 Rivas Mata, Emma, op. cit., p. 114 
Mateos, Guillermo Prieto o Juan de Dios Peza. ${ }^{29}$ El siguiente apartado documentará el caso de un académico mexicano que se inspiró en esa revista española para elaborar una periódica nacional.

\section{INFLUENCIA DE LA ILUSTRACIÓN ESPAÑOLA Y AMERICANA EN UNA PUBLICACIÓN MEXICANA}

Esta revista que dio fama a Abelardo de Carlos tuvo un gran impacto tanto entre escritores como editores mexicanos. Para los objetivos de este artículo, destaco el caso de los miembros de la Academia Mexicana Correspondiente de la Española, específicamente Agüeros, quien figuraba entre los redactores extranjeros de esa publicación. Este académico consideró que La Ilustración Española y Americana era el modelo que debía imitarse en la República Mexicana. Victoriano había establecido el periódico El Tiempo, el $1^{\circ}$ de julio de 1883. Una vez que esta publicación alcanzó aceptación y prestigio entre los lectores, su editor decidió introducir la Edición Ilustrada de El Tiempo, a partir del 5 de julio de 1891. Agüeros expresó con claridad que esta revista estaba inspirada en La Ilustración Española y Americana, y que en todo momento buscó elaborar:

un periódico ilustrado, semejante a los que se dan al público en todas las capitales de las grandes naciones del mundo. Eso pretendemos hacer, una Ilustración Mexicana, como la española, la francesa o la inglesa. Pretenderlo no es, sin embargo, lograrlo; pero claro es que para llegar a la perfección hay que ir gradualmente, paso a paso, máxime cuando se carece de todos los elementos constitutivos de ese género de periódicos. Avanzamos un poco; pero sin detenernos iremos adelante a medida que reunamos aquellos elementos. Unos vienen ya en camino; otros ya los tenemos en la mano. Cuando estén juntos, esperamos que no fracasara nuestro intento. ${ }^{30}$

Así, tanto el cabezal de la Edición Ilustrada de El Tiempo, como las imágenes que acompañaron los artículos de esa revista dominical, se inspiraron en La Ilustración Española y Americana. Como mencioné líneas atrás, Abelardo de Carlos incluyó el título de su publicación enmarca-

29 Pérez Montfort, Ricardo, op. cit., p. 291.

30 "Crónica". En El Tiempo, t. 1, n. 1, 5 jul. 1891, p. 1. 


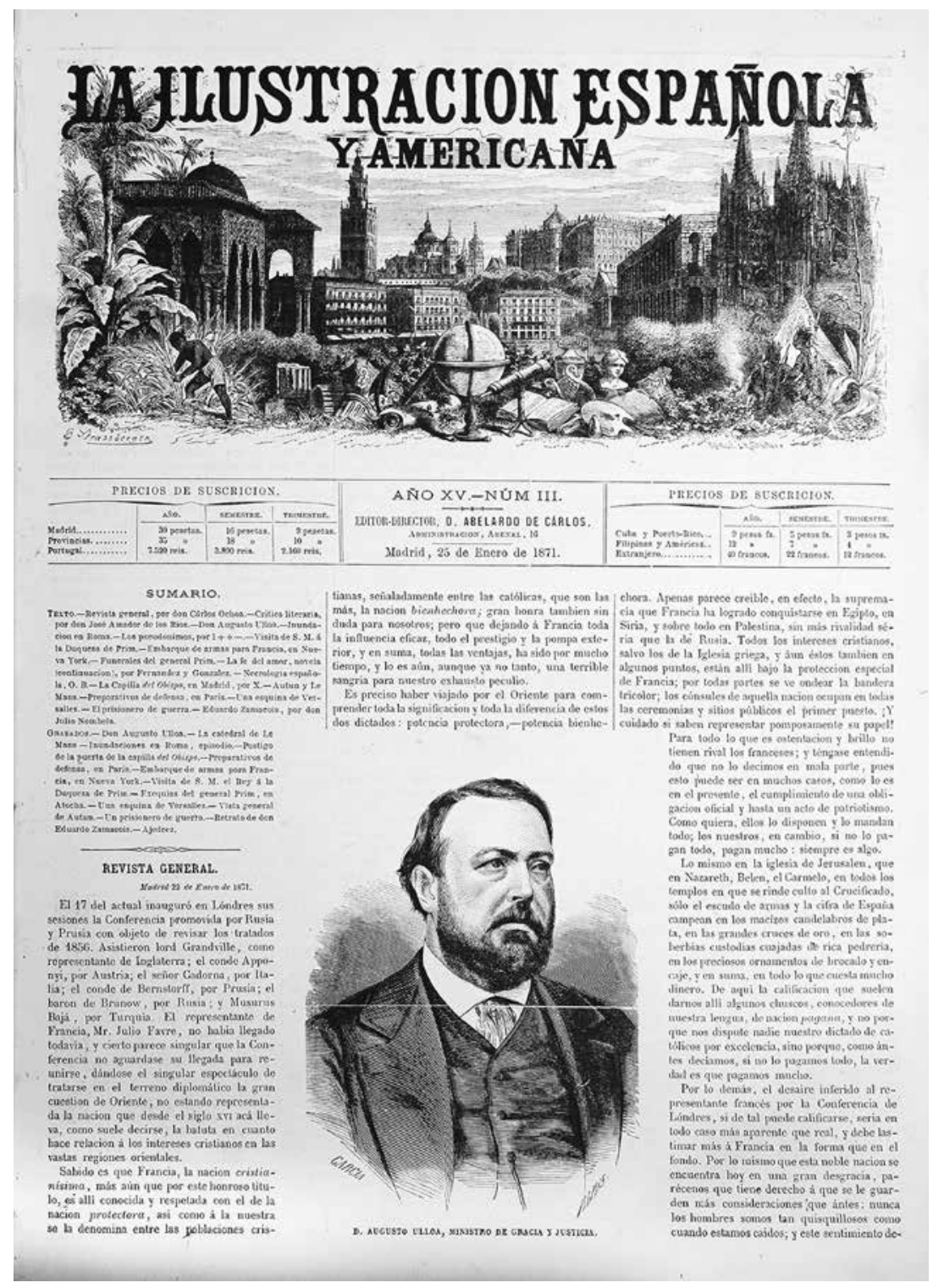

Ilustración 1. La Ilustración Española y Americana, 25 de enero de 1871. Fuente: Hemeroteca Nacional de México, Instituto de Investigaciones Bibliográficas, Universidad Nacional Autónoma de México. 


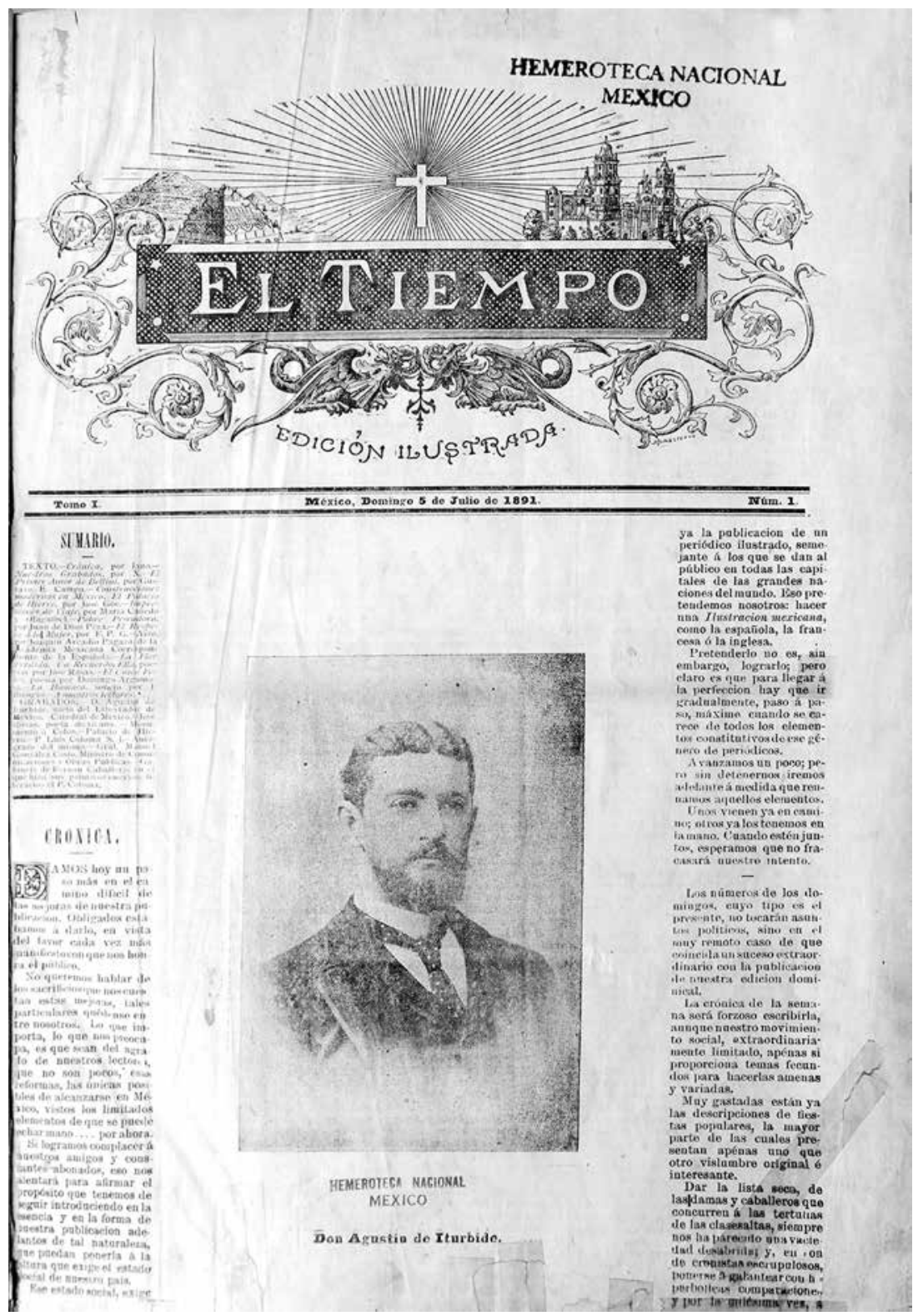

Ilustración 2. El Tiempo, 5 de junio de 1891. Fuente: Hemeroteca Nacional de México, Instituto de Investigaciones Bibliográficas, Universidad Nacional Autónoma de México. 
do con paisajes que simbolizaban los edificios más emblemáticos de las ciudades españolas y lugares exuberantes del continente americano. A través de ellos, trató de unir a España e Hispanoamérica por medio de la literatura y el idioma castellano. Por su parte, Agüeros, acorde con sus principios políticos y religiosos, colocó en el cabezal de El Tiempo. Edición Ilustrada, una cruz sobre el firmamento que alumbraba un paisaje conformado por dos montañas y una pirámide, colocadas en la parte izquierda del dibujo, y la Catedral de la Ciudad de México, que ilustraba el lado derecho de esa imagen. Bajo el título del periódico El Tiempo pueden verse dos águilas con garras de león colocadas frente a frente y que recuerdan un escudo de estilo europeo. También, de acuerdo al modelo de La Ilustración Española y Americana, Agüeros brindó artículos literarios e históricos que iban acompañados de imágenes. Así pues, este hecho es una prueba fehaciente del impacto que tuvo esa revista peninsular entre los miembros de la Academia Mexicana Correspondiente de la Española.

\section{PARA CONCLUIR}

Queda de manifiesto el interés de Abelardo de Carlos por contribuir a la grandeza de España a través de la labor editorial, que podía equipararse a la de otros países europeos, así como su afán por competir con el mercado editorial francés que monopolizaba el comercio del libro en Hispanoamérica. De este modo, La Ilustración Española y Americana rivalizó con El Correo de Ultramar, al brindar un producto cultural de calidad que tuvo una amplia circulación, distribución y aceptación en México, al grado de que sirvió como modelo para establecer revistas mexicanas similares a esa española.

Como pudo apreciarse, De Carlos empleó estrategias de venta y publicidad que le permitieron posicionar a La Ilustración Española y Americana en el mercado mexicano. Entre esos mecanismos se cuenta la relación con los miembros de la Real Academia Española que aprovecharon su experiencia en la elaboración de El Correo de Ultramar para facturar un producto similar y competitivo con esa empresa periodística de capital francés. Al mismo tiempo, los académicos peninsulares fomentaron, entre sus pares mexicanos, el consumo, colaboración y propaganda de esa revista en México. Por otro lado, el editor gaditano empleó las redes mercantiles y culturales que tendió con sus paisanos y colegas peninsu- 
lares residentes en México para generar el circuito de oferta, demanda, distribución e inclusive imitación.

De esta manera, puede señalarse la conjunción de intereses y afanes de académicos peninsulares y mexicanos por estrechar las relaciones entre ambas naciones a través de la lengua y las letras castellanas, proyecto en el que La Ilustración Española y Americana tuvo una participación destacada. Queda abierta la investigación para estudios comparativos entre Abelardo de Carlos con los mexicanos Ignacio Cumplido, Vicente García Torres o el propio Victoriano Agüeros. Así como el análisis de las imágenes que sobre México circularon en España a través de esta revista destinada a un lector con poder adquisitivo.

Por último, cabe decir que la mejor evidencia de que La Ilustración Española y Americana tuvo amplia distribución en México es el hecho de que sus ejemplares, que dan cuenta de poco más de medio siglo de existencia, se conservan duplicados y triplicados en el Fondo Reservado de la Hemeroteca Nacional. ${ }^{31}$

\section{FUENTES CONSULTADAS}

\section{Bibliografía}

Academia Mexicana de la Lengua, Anuario 2011, México, Academia Mexicana de la Lengua A.C., 2010.

Andrade, Vicente de P., Noticia de los periódicos que se publicaron durante el siglo XIX dentro y fuera de la capital, México, Tipografía de El Tiempo, 1901. Carnero, Guillermo, Historia de la literatura española. Siglo XIX (I), España, Espasa-Calpe, 1997.

Castro, Miguel Ángel, "La elite se ilustra. Revistas literarias en España y México a fines del siglo xIx: el ejemplo de Clarín y Micrós", Elites en México y España. Estudios sobre política y cultura, México, Universidad Nacional Autónoma de México-Instituto de Investigaciones Históricas/Universidad de Cantabria, 2015.

31 Los volúmenes duplicados y triplicados corresponden a la etapa en la que Abelardo de Carlos estuvo al frente de su edición, lo que deja ver el cuidado que tenía en enviar su producto a los países hispanoamericanos. A finales del siglo XIX y las primeras dos décadas del xx, hay huecos faltantes de la revista, lo que se explica tanto por el menor interés de los descendientes de De Carlos por el negocio, así como por las vicisitudes bélicas y económicas que enfrentaba España. 
Catálogo de las publicaciones periódicas madrileñas existentes en la Hemeroteca Municipal de Madrid 1661-1930, España, Artes Gráficas Municipales, 1933.

Cazottes, Giséle, La presse periodique madrilene entre 1871 et 1885, Francia, Centre de Recherchesur les Litteratures Ibériques et Ibéroamericaines Modernes, Universite Paul Valerie, Montpellier, 1982.

Celma Valero, María Pilar, Literatura y periodismo en las revistas del fin de siglo. Estudios e índices (1888-1907), Madrid, Ensayos Jucar, 1991.

Fernández, Pura, "En torno a la edición fraudulenta de impresos españoles en Francia: La Convención Literaria Hispano-Francesa (1853)", Estudios de literatura española de los siglos XIX y XX. Homenaje a Juan Díez Taboada, España, Consejo Superior de Investigaciones Científicas, 1998.

Gómez Aparicio, Pedro, Historia del periodismo español. Desde la Gaceta de Madrid (1661) hasta el destronamiento de Isabel II, España, Editora Nacional, 1967.

Historia del periodismo español. De la revolución de septiembre al desastre colonial, España, Editorial Nacional, 1971.

Hartzenbusch, Eugenio, Apuntes para un catálogo de periódicos madrileños. Desde el año 1661 al 1870, edición facsimilar, España, Biblioteca Nacional/Ministerio de Cultura/ Ollero y Ramos Editores, 1993.

Mora, Pablo, "Españoles en México en el siglo xIx: historiografía, crítica y periodismo literario", Miquel, Ángel, Nieto Sotelo, Jesús y Pérez Vejo, Tomás (comps.), Imágenes cruzadas. México y España, siglos XIX y XX, México, Universidad Autónoma del Estado de Morelos, 2005.

Mora, Pablo y Ángel Miquel (comp. y ed.), Españoles en el periodismo mexicano: siglo XIX y XX. México, Universidad Nacional Autónoma de México-Instituto de Investigaciones Bibliográficas, 2008.

Ossorio y Bernard, Manuel, Ensayo de un catálogo de periodistas españoles del siglo XIX, España, Imprenta y Litografía de J. Palacios, 1903.

Palenque, Marta, Gusto poético y difusión literaria en el realismo español. La Ilustración Española y Americana (1869-1905), Sevilla, Ediciones Alfar, 1990.

Palomo, Ma. del Pilar (ed.), Movimientos literarios y periodismo en España, España, Editorial Síntesis, 2010.

Pedraza Jiménez, Felipe B. y Milagros Rodríguez Cáceres, Manual de literatura española. VII. Época del realismo, España, Cénlit Ediciones, 1982.

Pérez Montfort, Ricardo, "La intelectualidad conservadora mexicana y Marcelino Menéndez y Pelayo. Impresiones de una relación a finales del siglo XIX y principios del XX", Aurora Cano Andaluz, Manuel 
Suárez Cortina y Evelia Trejo (eds.), Cultura liberal, México y España. 1860-1930. España, PUbliCan Ediciones de la Universidad de Cantabria/Universidad Nacional Autónoma de México-Instituto de Investigaciones Bibliográficas, 2010.

Rama, Carlos M., Historia de las relaciones culturales entre España y la América Latina. Siglo XIX, México, Fondo de Cultura Económica, 1982.

Rivas Mata, Emma, "Corresponsales hispanos del bibliógrafo mexicano Joaquín García Icazbalceta", Agustín Sánchez Andrés y Juan Carlos Pereira Castañares (coords.), España y México. Doscientos años de relaciones, 1810-2010. México, Universidad Michoacana de San Nicolás de Hidalgo-Instituto de Investigaciones Históricas/ Comisión para el Bicentenario de la Independencia y el Centenario de la Revolución/Comisión Española de Historia de las Relaciones Internacionales, 2010.

Romero Tobar, Leonardo, Historia de la literatura española. Siglo XIX (II), España, Espasa Calpe, 1998.

Sánchez Aranda, José Javier y Carlos Barrera, Historia del periodismo español. Desde sus orígenes hasta 1975, España, Ediciones de la Universidad de Navarra, 1992.

Sánchez Vigil, Juan Miguel, Revistas ilustradas en España del romanticismo a la guerra civil, España, Ediciones Trea, 2008.

Seoane, María Cruz, Historia del periodismo en España, II. El siglo XIX, España, Alianza Editorial, 1983.

Oratoria y periodismo en la España del siglo XIX, España, Fundación Juan March/Editorial Castalia, 1977.

Seoane, María Cruz y María Dolores Saiz, Cuatro siglos de periodismo en España. De los avisos a los periódicos digitales, España, Alianza editorial, 2007.

Tarín-Iglesias, José, Panorama del periodismo hispanoamericano. Desde sus orígenes hasta nuestros días, Madrid, Salvat Editores/Alianza Editorial, 1972.

Vega y Ortega, Rodrigo, "Microbios, fósiles y genes en una revista catalana en México, El Mundo Científico (1899-1911)", Adriana Pineda Soto y Fausta Gantús (coords.), Miradas y acercamientos a la prensa decimonónica, México, Universidad Michoacana de San Nicolás de Hidalgo/Red de Historiadores de la Prensa y el Periodismo en Iberoamérica, 2013.

Vieyra Sánchez, Lilia, "Apuntes biográficos de una revista y múltiples usos de la prensa: el caso de La Ilustración Española y Americana (1869- 
1879)", ponencia leída el 13 de noviembre de 2012 en el Coloquio la Prensa Fuente y objeto de la Multidisciplina en la Unidad de Investigación Multidisciplinaria de la Facultad de Estudios Superiores Acatlán.

"Identidad nacional: una revisión en dos periódicos españoles y dos mexicanos de la ciudad de México (1873-1879)", Manuel Suárez Cortina, Evelia Trejo Estrada y Aurora Cano Andaluz (eds.), Cuestión religiosa. España y México en la época liberal, México, Universidad Nacional Autónoma de México-Instituto de Investigaciones BibliográficasInstituto de Investigaciones Históricas-Dirección General de Asuntos del Personal Académico/Ediciones de la Universidad de Cantabria, 2012.

"La Real Academia Española y la Academia Mexicana Correspondiente de la Española. Dos instituciones elitistas, 18651875", Evelia Trejo Estrada, Aurora Cano Andaluz y Manuel Suárez Cortina (eds.), Elites en México y España. Estudios sobre política y cultura, México, Universidad Nacional Autónoma de México-Instituto de Investigaciones Históricas/Universidad de Cantabria, 2015.

"Los cimientos para el estudio de las publicaciones periódicas españolas del siglo XIX del Fondo Reservado de la Hemeroteca Nacional de México", ponencia leída en el Coloquio A 100 años del origen de la Hemeroteca Nacional de México, 25 de septiembre de 2013, Auditorio José María Vigil del Instituto de Investigaciones Bibliográficas.

\section{Referencias electrónicas}

Jara, Vivian, "Imagen de América Latina en La Ilustración Española y Americana, en el siglo XIX", Latina. Revista de Comunicación Social (12 de diciembre 1998), disponible en línea: http://www.ull.es/publicaciones/latina/a//02hvivian.htm [Consultado el 15 de diciembre de 2015].

"La Ilustración Española y Americana", Odisea 2008 (14 diciembre 2009), disponible en línea: http://www.odisea2008.com/2009/12/la-ilustracion-española-y-americana.html [Consultado 15 de diciembre de 2015].

“Ramón Padró y Pedret", Wikipedia. La Enciclopedia Libre, disponible en línea: https://es.wikipedia.org/wiki/Ramon_Padro_y_Pedret [Consultado 5 de diciembre de 2016].

Sablonniere, Catherine, "El Correo de Ultramar (1842-1886) y la ciencia: entre labor educativa y propaganda política". Ponencia presentada 
en el IV Encuentro Internacional de Historiadores de la Prensa en Iberoamérica, San Cristóbal de Las Casas, Chiapas, México, disponible en línea: http://historiadoresdelaprensa.com.mx |Consultado 2 de enero de 2014].

Sánchez García, Raquel, "La propiedad intelectual en la España contemporánea, 1847-1936", disponible en línea: http://eprints.ucm. es/16991/1/PROPIEDA.pdf [consultado 8 de diciembre 2016].

"Tratado entre los Estados Unidos Mexicanos y el Reino de España sobre propiedad literaria", 19 de septiembre de 1903. http://cdigital. dgb.uanl.mx/la/1080046961/1080046961_49.pdf |Consultado 8 de diciembre 2016].

Tratados sobre derecho de autor suscritos por México, México, Secretaría de Educación Pública/Instituto Nacional del Derecho de Autor, 2006, pp. 241-246, disponible en línea: http://www.indautor.gob.mx/ documentos_publicaciones/4m.pdf [Consultado 8 de diciembre 2016].

Vieyra Sánchez, Lilia. "Las publicaciones periódicas extranjeras en el siglo XIX en el Fondo Reservado de la Hemeroteca Nacional" Compendio XII Jornadas Académicas 2010. México, 2013, disponible en línea: http:// www.iib.unam.mx/files/Investigacion/Publicaciones/jornadas2010. pdf [Consultado el 30 de agosto de 2016].

\section{Hemerografía}

"Advertencias", La Ilustración Española y Americana, a 14, n. 1, (25 dic. 1869), p. 16.

Castro y Serrano, José de, “[Abelardo de Carlos y Almansa]", La Ilustración Española y Americana, a. 28, n. 13 (8 abr. 1884), pp. 210-211.

Fernández, Pura, "El monopolio del mercado internacional de impresos en castellano en el siglo XIX. Francia, España y 'la ruta' de Hispanoamérica", Bulletin Hispanique, t. 100, n. 1, (1998), pp. 165-190.

Fernández Bremon, José, "Crónica”, La Ilustración Española y Americana, a. 28, n. 13 (8 de abril de 1884), pp. 211-214.

Hernández Prieto, Ma. Isabel, "Escritores hispanoamericanos en La Ilustración Española y Americana (1869-1899)", Anales de literatura hispanoamericana, España, Madrid, n. 24 (1995), pp. 205-223.

Márquez, Miguel B., "D. Abelardo de Carlos y La Ilustración Española y Americana", Ámbitos, n. 13-14 (2005), pp. 185-209. 
Santiago Gómez, Arnulfo Uriel de, "Editar en Francia, siglo XIX. La 'librería española' para América", Anuario de Investigación 2005. Universidad Autónoma Metropolitana, (2006), pp. 682-698. "Las Ciencias Sociales en América Latina: Siglo XIX: Ediciones como primeras fuentes", Argumentos. Estudios críticos de la sociedad, (enero-abril 2013), pp. 13-35.

Vieyra Sánchez. Lilia, "Las revistas decimonónicas de España en el Fondo Reservado de la Hemeroteca Nacional de México". (En prensa en Nueva Gaceta Bibliográfica). 